Research Article

\title{
Karyotype diversity between species of Crenicichla (Perciformes, Cichlidae) from different Brazilian hydrographic basins
}

\author{
Larissa Bettin Pires ${ }^{1}$, Mariana Campaner Usso ${ }^{1}$, Lucia Giuliano-Caetano ${ }^{1}$ (D) and Ana Lúcia Dias ${ }^{1}$ (D) \\ ${ }^{1}$ Departamento de Biologia Geral, Centro de Ciências Biológicas, Universidade Estadual de Londrina, \\ Londrina, PR, Brazil.
}

\begin{abstract}
Crenicichla is the largest genus in the Cichlidae family in South America. The genus includes 100 valid species that are popularly known in Brazil as jacundás or joaninhas and are widely distributed in rivers east of the Andes. Cytogenetic analyses were carried out on seven species in this genus. All species showed a diploid number of 48 with interspecific differences in karyotype formulas and AgNORs located in interstitial position on the short arm of the largest metacentric pair, except for the two populations from $C$. britskii. Population A showed terminal markings on the long arm of the fifth pair of the complement, and population B showed up to two marked chromosome pairs. FISH with an $18 \mathrm{~S}$ rDNA probe was coincident with AgNORs and $\mathrm{CMA}_{3}$, except for pair 6 from population $\mathrm{B}$ of $C$. britskii that did not presented positive $\mathrm{CMA}_{3}$ sites. This work presents first cytogenetic data for $C$. haroldoi, $C$. maculata, and $C$. punctata, and the results show karyotypic patterns similar to those in the literature. However, the diversity found in populations of $C$. britskii represents new information about the evolution of the karyotype of the Cichlidae family, which has been conservative. Furthermore, the data could assist in phylogenetic studies of Crenicichla.
\end{abstract}

Keywords: Chromosome banding, fish cytogenetics, Geophaginae, ribosomal DNA.

Received: February 20, 2018; Accepted: July 17, 2018.

\section{Introduction}

The Cichlidae family includes a wide variety of fish species and is one of the largest in Perciformes. There are approximately 1706 valid species (Eschmeyer and Fong, 2018), and the group is considered highly specialized (Kullander, 1998). Through cladistics morphological analyses, Kullander (1998) verified that this family is a monophyletic group and showed a dichotomy between "Old World" and "New World" cichlids.

Stiassny (1991) first recognized the monophyletism of Neotropical cichlids, which include more than 406 valid species (Kullander, 2003). This was later confirmed by phylogenetic relationships based on molecular data (Farias et al., 1999; López-Fernández et al., 2010) and combinations of morphological and molecular data (Farias et al., 2000; López-Fernández et al., 2005; Smith et al., 2008). Among Neotropical cichlids, the genus Crenicichla is one of the most numerous, with 100 valid species described (Frose and Pauly, 2018). The pike cichlids are easily recognized by their elongated body, large mouth, and prognata. These cichlids mostly occur in tropical and subtropical regions of South America, from the coastal drainages of Ven-

Send correspondence to Ana Lúcia Dias. Departamento de Biologia Geral, Centro de Ciências Biológicas, CCB, Universidade Estadual de Londrina, P.O Box 6001, 86051-970 Londrina, PR, Brazil. E-mail: anadias@uel.br. ezuela and Guiana to the Plata River in Argentina (Kullander and Lucena, 2006).

This genus has been studied extensively from a cytogenetic point of view, with the first work conducted by Oyhenart-Perera et al. (1975) on Crenicichla sexatilis. Since then, several studies have been carried out, and the majority identify only the diploid number ( $2 n)$, with a total of 19 species analyzed to date presenting a conserved $2 \mathrm{n}$ equal to 48 , according to cytogenetic surveys performed by Feldberg et al. (2003) and Benzaquem et al. (2008). Only Crenicichla sp. does not present 48 chromosomes, showing $2 \mathrm{n}=46$ (Rezende et al., 1996). The phylogenetic position of Crenicichla within the family is quite controversial, sometimes being assigned to the clade Cichlinae (Stiassny, 1991; Kullander, 1998) and sometimes to the clade Geophaginae (Farias et al., 2000; López-Fernández et al., 2005; Landim, 2006; Smith et al., 2008).

Thus, the aim of this work was to perform conventional and molecular cytogenetic analyses of seven pike cichlids species: Crenicichla britskii, C. lepidota, C. niederleinii, C. semifasciata, C. punctata, C. haroldoi, and C. maculata. The results provide the first karyotypic information for the last three species. The data presented could be used as an additional tool for phylogenetic studies and help to better define relations within the genus, as well as improve the understanding of the karyotype evolution of the group. 


\section{Materials and Methods}

The seven species studied were collected from four Brazilian hydrographic basins (Table 1).The specimens were deposited in the Museum of Zoology at the State University of Londrina, Parana, Brazil. For convenience, different populations of $C$. britskii were called population A (Taquari) and population B (Paranapanema), as shown in Table 1.

Mitosis was stimulated by the injection of yeast suspension in animals, as described by Lee and Elder (1980). Mitotic chromosomes were obtained by direct preparation by removing the anterior kidney according to the methodology proposed by Bertollo et al. (1978), and slides for conventional analysis were stained with $5 \%$ Giemsa stain in phosphate buffer at $\mathrm{pH}$ 6.8. The morphology of the chromosomes was determined based on the ratio of arms, as proposed by Levan et al. (1964). For determination of the fundamental number (FN), the metacentric (m) and submetacentric (sm) chromosomes were considered biarmed and the subtelo-acrocentric (st-a) uniarmed.

Nucleolar organizer regions (NORs) were detected by impregnation with silver nitrate according to the technique described by Howell and Black (1980). GC- and AT-rich sites were detected with chromomycin $\mathrm{A}_{3}\left(\mathrm{CMA}_{3}\right)$ and 4', 6-diamino-2-phenylindole (DAPI) according to Schweizer (1980). Fluorescence in situ hybridization (FISH) was performed according to the protocol from Pinkel et al. (1986) with modifications according Gouveia et al. (2013) using a 18S rDNA probe (Hatanaka and Galetti $\mathrm{Jr}, 2004)$. Finally, the slides were analyzed on an epifluorescence microscope (Leica DM2000), which was attached to a digital camera. Metaphase images were captured using Leica Application Suite version 3.1.0. (Leica Microsystems).

\section{Results}

All species analyzed showed a diploid number (2n) of 48 chromosomes, but four different karyotype formulas among species were observed: $6 \mathrm{~m}+4 \mathrm{sm}+38 \mathrm{st}-\mathrm{a}$ and $\mathrm{FN}=58$ for C. haroldoi (Figure 1a), $4 \mathrm{~m}+6 \mathrm{sm}+38 \mathrm{st}-\mathrm{a}$ and $\mathrm{FN}=58$ for C. britskii, C. niederleinii, and C. punctata (Figure 1b-d and Figure 2c), $6 \mathrm{~m}+42 \mathrm{st}-\mathrm{a}$ and $\mathrm{FN}=54$ for $C$. maculata and C. lepidota (Figure 2a,b), and $4 \mathrm{~m}+44 \mathrm{st}-\mathrm{a}$ and $\mathrm{FN}=52$ for $C$. semifasciata (Figure 2d).

AgNORs were located on a pair of chromosomes for all species (Figure 1a,b,d and Figure 2a-d), except for population B from C. britskii, which showed up to two marked chromosome pairs (Figure 1c). Population A of C. britskii showed terminal markings on the long arm of the fifth pair of the complement (sm) (Figure 1b). All other species showed NORs in an interstitial location on the short arm of the largest metacentric pair (boxes in Figure 1a,d and Figure $2 a-d)$.

The AgNORs were coincident with the secondary constrictions observed by Giemsa staining. Exceptions were observed in C. britskii. In population A, the secondary constriction observed in pair 20 was not a positive AgNOR, only the constriction of pair 5 (Figure $1 \mathrm{~b}$, box). In population B, pair 5 showed a heteromorphism of NORs in the long arm coincident with the secondary constriction, and pair 6 showed a heteromorphism of NORs in the short arm that was not coincident with secondary constriction (Figure 1c, box).

For all species of Crenicichla the FISH analysis with the $18 \mathrm{~S}$ rDNA probe was coincident with AgNORs (Figures 1 and 2).

Staining with $\mathrm{CMA}_{3}$ showed fluorescent markings coinciding with the NORs in all species analyzed (Figures 1 and 2), except pair 6 from population $\mathrm{B}$ of $C$. britskii. In this population, there was an additional positive $\mathrm{CMA}_{3}$ pair (pair 1), as shown in Figure 1c. Size heteromorphism with $\mathrm{CMA}_{3}$ occurred in pair 5 of $C$. britskii from population B and in pair 1 of $C$. niederleinii and C. maculata, as evidenced by Giemsa staining and with the 18S rDNA probe (Figure 1c,d, Figure 2a, Table 2). In DAPI staining, the NORs did not showed fluorescent signals, appearing only as a negative band (Figures 1 and 2).

Table 1 - Collection sites and hydrographic basins of Crenicichla specimens analyzed. MS = Mato Grosso do Sul; PR=Paraná; RS=Rio Grande do Sul

\begin{tabular}{|c|c|c|c|}
\hline Species & Collection sites & Hydrographic basins & Number of individuals \\
\hline Crenicichla britskii & $\begin{array}{l}\text { Taquari stream-PR (A) } 23^{\circ} 10^{\prime} 45.2^{\prime} \mathrm{S} 50^{\circ} 56^{\prime} 30.9^{\prime \prime}, \mathrm{W} \\
\text { Paranapanema-SP (B) } 22^{\circ} 42^{\prime} 30.3^{\prime \prime} \mathrm{S} 51^{\circ} 04^{\prime} 08.4^{\prime \prime} \mathrm{W}\end{array}$ & Paranapanema river & $7 \mathrm{M}, 6 \mathrm{~F}$ \\
\hline C. haroldoi & Pavão stream / PR & Paranapanema river & $2 \mathrm{M}, 2 \mathrm{~F}$ \\
\hline C. niederleinii & 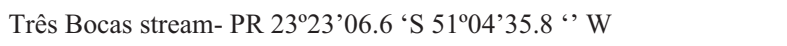 & Paranapanema river & $2 \mathrm{M}, 5 \mathrm{~F}$ \\
\hline C. lepidota & Miranda river-MS $19^{\circ} 34^{\prime} 38.01$ 'S 5701'06.63'W & Paraguai river & $1 \mathrm{M}, 2 \mathrm{~F}$ \\
\hline C. maculata & Maquiné river-RS $29^{\circ} 39^{\prime} 10.4$ 'S $50^{\circ} 12^{\prime} 31.8^{\prime \prime}$ W & Tramandaí river & $2 \mathrm{M}, 4 \mathrm{~F}$ \\
\hline C. lepidota & Barra do João Pedro-RS $29^{\circ} 46^{\prime} 21.2$ 'S 5005’08.0’’ W & Tramandaí river & $3 \mathrm{M}, 3 \mathrm{~F}, 3 ?$ \\
\hline C. punctata & $\begin{array}{l}\text { Saco da Alemoa and river Forqueta-RS } 29^{\circ} 22^{\prime} 08.0 \text { ' } \mathrm{S} 52^{\circ} 03^{\prime} 30.0^{\prime \prime} \mathrm{W} \\
\text { Total of individuals: } \mathbf{5 0}\end{array}$ & Laguna dos Patos System & $2 \mathrm{M}, 5 \mathrm{~F}$ \\
\hline
\end{tabular}

M: male. F: female. 


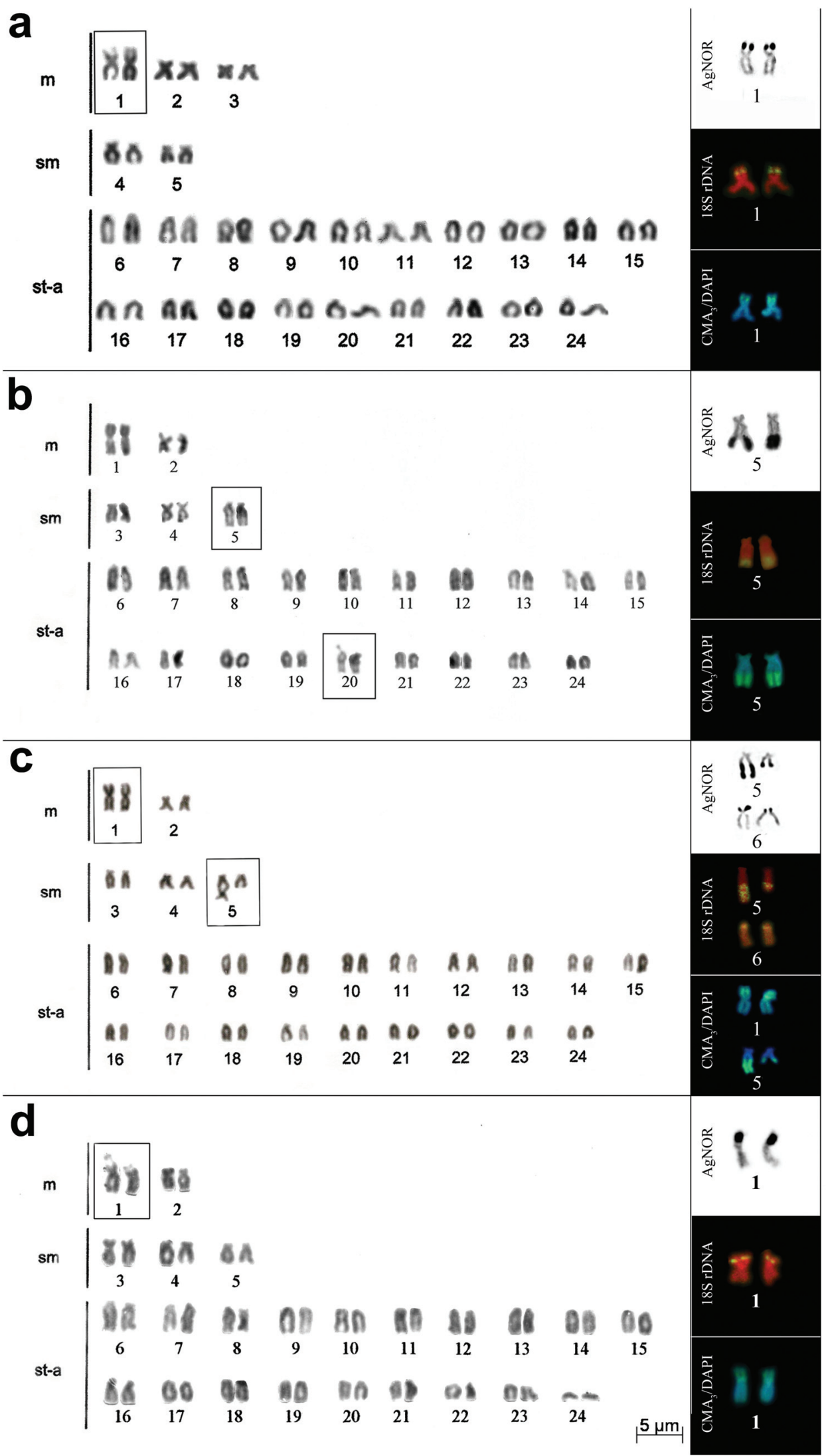

Figure 1 - Karyotype and chromosome pairs with silver nitrate staining, FISH with $18 \mathrm{~S}$ rDNAr probe and $\mathrm{CMA}_{3} / \mathrm{DAPI}$ in: Crenicichla haroldoi (a), $C$. britskii, populations A (b) and B (c), and C. niederleinii (d), respectively. In the boxes are secondary interstitial constrictions in the short arm of the first metacentric pair (a,d) and in the long arm of the fifth pair (b, c). 
a

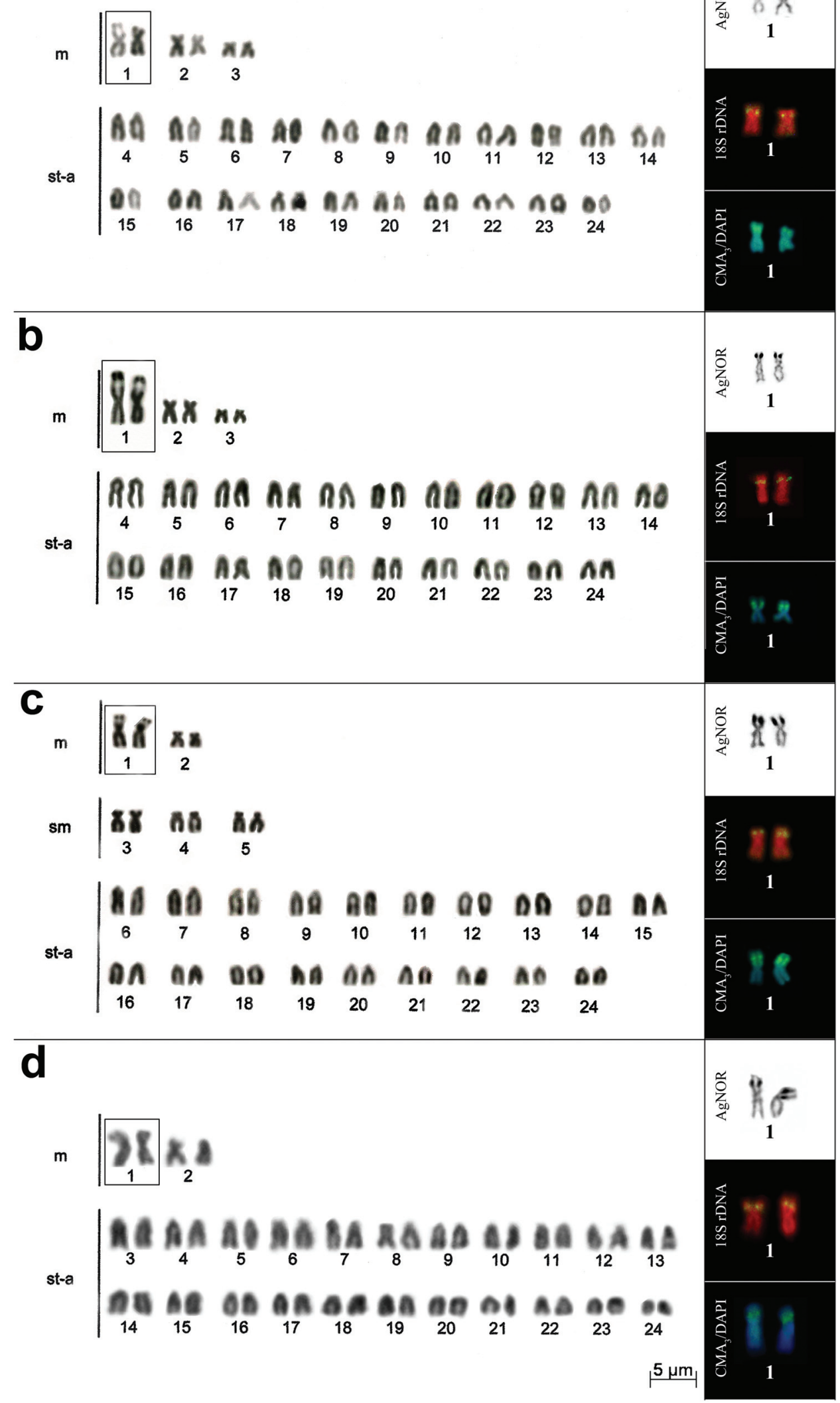

Figure 2 - Karyotype and chromosome pairs with silver nitrate staining, FISH with $18 \mathrm{~S}$ rDNAr probe and $\mathrm{CMA}_{3} / \mathrm{DAPI}$ in: Crenicichla maculata (a), $C$. lepidota (b), C. punctata (c) and C. semifasciata (d), respectively. In the boxes are secondary interstitial constrictions in the short arm of the first metacentric pair. 


\section{Discussion}

These are the first cytogenetic data for C. haroldoi, $C$. maculata and C. punctata. Along with data for C. lepidota, C. niederleinii, C. semifasciata, and C. britskii, all results presented a conserved diploid number $(2 \mathrm{n}=48)$, corroborating data from the literature (Feldberg et al., 2003; Benzaquem et al., 2008). Thus far, all species of Crenicichla have shown this pattern, except Crenicichla sp studied by Rezende et al. (1996), which presented $2 \mathrm{n}=46$. The $\mathrm{FN}$ is also consistent with the variations of 52 to 64 found in the literature (Pires, 2013). Despite the conservation of the diploid number, variations in the karyotype formulae were found in C. semifasciata, C. niederleinii and C. britskii in relation to other populations of these species (Feldberg and Bertollo, 1985a,b; Martins et al., 1995; Benzaquem et al., 2008; Poletto et al., 2010). Such differences can be attributed to pericentric inversion events, which play an important role in the karyotype diversity of these species, as suggested by Feldberg and Bertollo (1985a).

According to Thompson (1979), the cichlids have 48 chromosomes of the subtelo-acrocentric type in basal species, where the presence of meta-submetacentric chromosomes would mean a derived karyotype. Furthermore, a greater presence of acrocentric chromosomes indicates a more ancestral karyotype. This hypothesis is shared by Feldberg et al. (2003), who consider the genus Crenicichla to be more derived because of the presence of meta- and submetacentric chromosomes. Considering this information, the genus Crenicichla is closer to Geophaginae, since the clade Cichlinae would be more ancestral because it presents mainly species with only subtelo-acrocentric chromosomes, as in the genus Cichla (Poletto et al., 2010).

Another characteristic shared between the species analyzed, except for population A of C. britskii, was the presence of a secondary interstitial constriction on the first chromosome pair. This seems to be a chromosome characteristic of this genus and perhaps a cytotaxononomic marker, because it is also observed in C. lacustris, $C$. semifasciata, and C. vittata (Feldberg and Bertollo, 1985a,b), C. lepidota (Martins et al., 1995; Perazzo et al., 2011; Poletto et al., 2010), Crenicichla sp., C. niederleinii (Loureiro et al., 2000), C. iguassuensis (Mizoguchi et al., 2007), and C. reticulata (Benzaquem et al., 2008). This particular chromosome of the genus is another characteristic and makes this group similar to the clade Geohaginae, since other genera of this clade also present this type of chromosome, such as Gymnogeophagus balzanii (Feldberg and Bertollo, 1984; Roncati et al., 2007), Gymnogeophagus labiatus (Pires et al., 2010); Geophagus surinamensis (Feldberg and Bertollo, 1985a), and Geophagus proximus (Valente et al., 2012).

Interestingly, population $\mathrm{A}$ of $C$. britskii did not show this constriction in the interstitial region but in the terminal region of the long arm of a submetacentric chromosome pair. Another interesting fact is that both populations of C. 
britskii presented a secondary constriction in the long arm in pair 20 (population A) and pair 5 (population B). The occurrence of these additional secondary constrictions has never been reported and may indicate a differential characteristic for this species.

The presence of a simple interstitial NOR in the first chromosome pair in all species, except Crenicichla britskii, and coincident with the secondary constriction, is well conserved in this genus, as reported by Loureiro et al. (2000), Roncati et al. (2007), Benzaquem et al. (2008) and Valente et al. (2012), among others. This trait varies only in the type of chromosomes, which may be metacentric (Martins et al., 1995; Loureiro et al., 2000; Mizoguchi et al., 2007), or submetacentric (Martins et al., 1995).

Occurrence of multiple NORs in population B of $C$. britskii may indicate that this population presents characteristics that are more derived in relation to the same species studied by Benzaquem et al. (2008) from another locality, which showed only a pair of NOR. This multiple pattern was previously reported in the genus, but only in $C$. lepidota from the region of Puerto Rico in the Paraná River basin (Martins et al., 1995), which is a different situation from that found in C. lepidota in the present study.

All analyzed species of Crenicichla, except population B of C. britskii, showed only a pair of chromosomes with ribosomal cistron $18 \mathrm{~S}$, thus corroborating the data obtained by the impregnation of silver nitrate and the ancestral condition proposed by Feldberg et al. (2003). The hybridization signals were located interstitially on the short arm of the largest chromosome pair of the complement, similar to previously reported for C. lepidota (Perazzo et al., 2010; Poletto et al., 2010), the only species of the genus to date with results of in situ hybridization.

Size heteromorphism in the NORs, as found in pair 5 in C. britskii (population B), C. niederleinii and $C$. maculata, may be the result of irregular crossover or differential amplification of this region among the homologous chromosomes. This has previously been proposed for other fishes, including Cichlidae (Pires et al., 2008; Gross et al., 2010; Poletto et al., 2010). The staining with $\mathrm{CMA}_{3}$ fluorochome evidenced fluorescent signals coincident with the NORs for the seven species, indicating the predominance of GC bases. However, population B of C. britskii again presented a distinct pattern with only one of the nucleolar pairs (pair 5) as $\mathrm{CMA}_{3}$ positive. NORs were negative for DAPI, thus revealing a scarcity of AT bases. The data with fluorochromes coincide with those reported for the genus by Loureiro et al. (2000), Perazzo et al. (2011), Mizoguchi et al. (2007), and Valente et al. (2012).

Among the species analyzed, C. britskii presented unique characteristics, despite having the same diploid number as the others members of the genus. The cytogenetic differences observed among the two populations of C. britskii may have resulted from geographic isolation between them. Ploeg (1991) also studied this species and found that it was endemic to the basin of Alto Paraná. This endemism resulted from the small displacement capacity of these fish: because they are highly territorial, they generally do not perform extensive migration throughout their life cycle and remain isolated (Castro, 1999).

According to Oliveira et al. (1988), populations that have less mobility and fewer individuals are more unstable in relation to their karyotype macrostructure. Gene flow is smaller, thus providing a higher rate of fixation of some chromosomal abnormality. This may be happening with the two populations of $C$. britskii, where geographic isolation would facilitate the establishment of chromosomal rearrangements and lead to a process of speciation. The population of $C$. britskii from the Paranapanema River has characteristics that are more derived when compared with the population from the Taquari Stream.

The results for the other species of Crenicichla show that karyotype patterns were similar to those found in the literature (Benzaquem et al., 2008), indicating a conservative trend in chromosome evolution in this group of fish. However, the karyotype diversity found in populations of C. britskii provides new information about the karyotype evolution of the Cichlidae family. The cytogenetic characteristics that are particular to Crenicichla can be an important tool for phylogenetic studies in this group of fish, such as the largest pair of complement with secondary interstitial constriction and the presence of meta/sub metacentric chromosomes in the karyotype. This places the genus Crenicichla in the clade Geophaginae, which corroborates the phylogeny proposed by López-Fernández et al. (2005) and Smith et al. (2008).

\section{Acknowledgments}

The authors thank Prof. Dr. Luiz Roberto Malabarba of the Zoology Laboratory at the Universidade Federal do Rio Grande do Sul (UFRGS), for the identification of specimens. This research was supported by Coordenação de Aperfeiçoamento de Pessoal de Nível Superior (CAPES) and Conselho Nacional de Desenvolvimento Científico e Tecnológico $(\mathrm{CNPq})$. The research received permission from the Instituto Brasileiro do Meio Ambiente e dos Recursos Naturais Renováveis (IBAMA) to collect fish specimens.

\section{Conflicts of interest}

The authors have no conflicts of interest to declare.

\section{Author contributions}

ALD, LBP conceived and designed the study; LGC, LBP collected the samples; LBP, perfomed the cytogenetic analysis; LBP, MCU, wrote the manuscript and designed the figures, all authors read and approved the final version. 


\section{References}

Benzaquem DC, Feldberg E, Porto JIR, Gross MC and Zuanon JAS (2008) Cytotaxonomy and karyoevolution of the genus Crenicichla (Perciformes, Cichlidae). Genet Mol Biol 31:250-255.

Bertollo LAC, Takahashi CS and Moreira-Filho O (1978) Cytotaxonomic considerations on Hoplias lacerdae (Pisces, Erythrinidae). Braz J Genet 1:103-120.

Castro RMC (1999) Evolução da ictiofauna de riachos sulamericanos: padrões gerais e possíveis processos causais. In: Caramaschi EP, Mazzoni R and Peres-Neto PR (eds) Ecologia de peixes de riachos. Pós-Graduação em Educação da Universidade Federal do Rio de Janeiro, Rio de Janeiro, pp 139-155.

Farias IP, Ortí G and Meyer A (1999) Mitochondrial DNA phylogeny of the family Cichlidae: Monophyly and fast molecular evolution of the Neotropical assemblage. J Mol Evol 48:703-711.

Farias IP, Ortí G, Sampaio I, Schneider H and Meyer A (2000) Total evidence: Molecules, morphology, and the phylogenetics of cichlid fishes. J Exp Zool 288:76-92.

Feldberg E and Bertollo LAC (1984) Discordance in chromosome number among somatic and gonadal tissue cells of Gymnogeophagus balzanii (Pisces: Cichlidae). Braz J Genet 4:639-645.

Feldberg E and Bertollo LAC (1985a) Karyotypes of 10 species of neotropical cichlids (Pisces, Perciformes). Caryologia 38:257-268.

Feldberg E and Bertollo LAC (1985b) Nucleolar organizing regions in some species of neotropical cichlid fish (Pisces, Perciformes). Caryologia 38:319-324.

Feldberg E, Porto JIR and Bertollo LAC (2003) Chromosomal changes and adaptation of cichlid fishes during evolution. In: Val AL and Kapoor BG (eds) Fish adaptations. Science publishers, New Dehli, New York, 418 pp.

Gouveia JG, Moraes VPO, Sampaio TR, Rosa R and Dias AL (2013) Considerations on karyotype evolution in the genera Imparfinis Eigenmann and Norris 1900 and Pimelodella Eigenmann and Eigenmann 1888 (Siluriformes: Heptapteridae). Rev Fish Biol Fisheries 23:215-227

Gross MC, Schneider CH, Valente GT, Martins C and Feldberg E (2010) Variability of 18S rDNA locus among Symphysodon fishes: chromosomal rearrangements. J Fish Biol 76:1117-1127.

Hatanaka T and Galetti Jr PM (2004) Mapping of the 18S and 5S ribosomal RNA genes in the fish Prochilodus argenteus Agassiz, 1829 (Characiformes, Prochilodontidae). Genetica 122:239-244.

Howell WM and Black DA (1980) Controlled silver staining of nucleolus organizing regions with a protective colloidal developer: a one step method. Experientia 36:1014-1015.

Kullander SO (1998) A phylogeny and classification of the South American Cichlidae (Teleostei: Perciformes). In: Malabarba LR, Reis RE, Vari RP, Lucena ZMS and Lucena CAS (eds) Phylogeny and classification of Neotropical fishes. Edipucrs, Porto Alegre, pp. 461-468.

Kullander SO (2003) Family Cichlidae. In: Reis RE, Kullander SO and Ferraris Jr CJ (eds) Check list of the freshwater fishes of South and Central America. Edipucrs, Porto Alegre, pp 605-654.
Kullander SO and Lucena CAS (2006) A review of the species of Crenicichla (Teleostei: Cichlidae) from the Atlantic coastal rivers of southeastern Brazil from Bahia to Rio Grande do Sul states, with descriptions of three new species. Neotrop Ichthyol 4:127-146.

Lee MR and Elder FFB (1980) Yeast simulation of bone marrow mitosis for cytogenetic investigations. Cytogenet Cell Genet 26:36-40

Levan A, Fredga K and Sandberg AA (1964) Nomenclature for centromeric position on chromosome. Hereditas 52:201204.

López-Fernández H, Honeycutt RL, Stiassny MLJ and Winemiller KO (2005) Morphology, molecules, and character congruence in the phylogeny of South American geophagine cichlids (Perciformes: Cichlidae). Zool Scripta 34:627-651.

López-Fernández H, Winemiller KO and Honeycutt RL (2010) Multilocus phylogeny and rapid radiations in Neotropical cichlid fishes (Perciformes: Cichlidae: Cichlinae). Mol Phylogenet Evol 55:1070-1086.

Loureiro MA, Giuliano-Caetano L and Dias AL (2000) Cytogenetic characterization of two species of the genus Crenicichla (Pisces, Cichlidae). Cytologia 65:57-63.

Martins IC, Portella-Castro ALB and Júlio Jr HF (1995) Chromosomes analysis of 5 species of the Cichlidae family (Pisces, Perciformes) from the Parana river. Cytologia 60:223-231.

Mizoguchi SMHK, Portella-Castro ALB and Martins-Santos IC (2007) Cytogenetic characterization of Crenicichla (Pisces, Perciformes, Cichlidae) of the Iguaçu river. Genet Mol Res 6:650-656.

Oliveira CLF, Almeida-Toledo LM, Foresti F, Britski HA and Toledo-Filho SA (1988) Chromosome formulae of neotropical freshwater fishes. Braz J Genet 11:577-624.

Oyhenart-Perera MF, Luengo JA and Brum-Zorilla N (1975) Estudio citogenetico de Cichlasoma facetum (Jenyns) y Crenicichla sexatilis (Linn.) (Teleostei. Cichlidae). Rev Biol Uruguay 3:29-36.

Perazzo G, Noleto RB, Vicari MR, Machado PC, Gava A and Cestari MM (2011) Chromosomal studies in Crenicichla lepidota and Australoheros facetus (Cichlidae, Perciformes) from extreme southern Brazil. Rev Fish Biol Fisheries 21: 509-515.

Pinkel D, Straume T and Gray JW (1986) Cytogenetic analysis using quantitative, high sensitivity fluorescence hybridization. Proc Natl Acad Sci USA 83:2934-2938.

Pires LB, Giuliano-Caetano L and Dias AL (2008) Karyotype similarities among two populations of Geophagus brasiliensis (Perciformes, Cichlidae) from the Tibagi river basin/PR/Brazil. Caryologia 61:135-138.

Pires LB, Giuliano-Caetano L and Dias AL (2010) Cytogenetic characterization of Geophagus brasiliensis and two species of Gymnogeophagus (Cichlidae: Geophaginae) from Guaíba Lake, RS, Brazil. Folia Biol 58:29-34.

Poletto AB, Ferreira IA, Cabral-de-Mello DC, Nakajima RT, Mazzuchelli J, Ribeiro HB, Venere PC, Nirchio M, Kocher TD and Martins C (2010) Chromosome differentiation patterns during cichlid fish evolution. BMC Genetics 11:50.

Ploeg A (1991) Revision of the South American cichlid genus Crenicichla Heckel, 1840, with descriptions of fifteen new species and considerations on species groups, phylogeny and biogeography (Pisces, Perciformes, Cichlidae)., Universiteit Van Amsterdam, Amsterdam, pp 1-153. 
Rezende AB, Queiroz CC, Caldart FA, Ribeiro L and Miyazawa CS (1996) Notas preliminares do estudo cariotípico de distintos grupos de peixes da bacia do Rio Paraguai, no estado do Mato Grosso. In: VI Simpósio de citogenética evolutiva aplicada em peixes neotropicais, São Carlos, p. 105.

Roncati HA, Pastori MC and Fenocchio AS (2007) Cytogenetic studies and evolutive considerations on fishes of the family Cichlidae (Perciformes) from Parana River (Argentina). Cytologia 72:379-384.

Schweizer D (1980) Simultaneous fluorescent staining of R bands and specific heterochromatic regions (DA/DAPI) in human chromosomes. Cytogenet Cell Genet 27:190-193.

Smith WL, Chakrabarty P and Sparks JS (2008) Phylogeny, taxonomy, and evolution of Neotropical cichlids (Teleostei: Cichlidae: Cichlinae). Cladistics 24:625-641.

Stiassny MLJ (1991) Phylogenetic intrarelationships of the family Cichlidae: An overview. In: Keenleyside MHA (ed) Cichlid Fishes: Behaviour, Ecology and Evolution. Chapman Hall, London, pp 1-35.

Thompson KW (1979) Cytotaxonomy of 41 species of Neotropical Cichlidae. Copeia 4:679-691.

Valente GT, Andrade Vitorino C, Cabral-de-Mello DC, Oliveira C, Lima Souza I, Martins C and Venere PC (2012) Compar- ative cytogenetics of ten species of cichlid fishes (Teleostei, Cichlidae) from the Araguaia River system, Brazil, by conventional cytogenetic methods. Comp Cytogenet 6:163-181.

\section{Internet Resources}

Eschmeyer WN and Fong JD (2018) Species by family/subfamily in the catalog of fishes, http://research.calacademy.org/redirect?url=http://researcharchive.calacademy.org/research/Ichthyology/catalog/SpeciesByFamily.asp (accessed 15 January 2018).

Frose R and Pauly D (2018) Catalogue of Life: FishBase, http:// www.fishbase.org.version (accessed 15 January 2018).

Pires LB (2013) Citogenética comparativa e evolutiva em peixes da família Cichlidae: ênfase para cromossomos B e a localização de genes de RNAr localização de genes de RNAr 18S. D. Sc. Thesis, Universidade Estadual de Londrina, Londrina.

Associate Editor: Catarina S. Takahashi

License information: This is an open-access article distributed under the terms of the Creative Commons Attribution License (type CC-BY), which permits unrestricted use, distribution and reproduction in any medium, provided the original article is properly cited. 